СМАРТ-ТАЪЛИМ - СМАРТ ШАХАРЛАР УЧУН

DOI: $10.53885 /$ edinres.2021.48.34.038

Э. Х. Юсупов

Тадбиркорлик ва педагогика институти “Табиий фанлар” кафедраси ўқитувчиси

\title{
УМНОЕ ОБРАЗОВАНИЕ - ДЛЯ УМНЫХ ГОРОДОВ
}

\author{
Э. Х. Юсупов
}

Преподаватель кафедры «Естественные науки» Института предпринимательства и педагогики

\section{SMART EDUCATION - FOR SMART CITIES \\ E. Kh. Yusupov \\ Lecturer at the Department of Natural Sciences, Institute of Entrepreneurship and Pedagogy}

Abstract: Background. In the twentieth century, various technologies were introduced in education, but not all technologies were successful in the educational process. Typically, all past technologies were teacher-centered, they were tools designed to work in conjunction with traditional teaching methods, and did not attract new generations of learners rapidly moving up the digital adoption curve. And now, in the 21st century, the development of an intelligent educational system presupposes a more successful application of digital technologies. To do this, educators must turn to innovation based on student-teacher collaboration. The article is written about the need to use smart technologies in the educational process.

Methods. The methods of pedagogical observation, comparative analysis, study of documents, stratification was used in the preparation of the article.

Results. The article discusses the use of smart technology tools as smart boards, sensor tables and others.

Conclusion. In conclusion, thoughts are given about the need to change the educational environment itself, not just to increase the volume of education of labor resources, to qualitatively change the content of education itself, its methods, tools and environments, as well as a general transition to SMART education.

Keywords: smart city, smart education, smart technologies, smart board, tools.

Introduction. In the twentieth century, various technologies were introduced in education, but not all technologies were successful in the 
educational process. Typically, all past technologies were teacher-centered, they were tools designed to work in conjunction with traditional teaching methods, and did not attract new generations of learners rapidly moving up the digital adoption curve. And now, in the 21st century, the development of an intelligent educational system presupposes a more successful application of digital technologies. To do this, educators must turn to innovation based on student-teacher collaboration.

Today, "smart cities" are being built in Uzbekistan (SMART CITY, Tashkent CITY). These cities need smart education. This education is a key component in the development of smart cities. The strengths of basic education, continuing education and certification, schools and community colleges, e-learning infrastructure, lifelong learning and educational technology innovation are all part of what defines a smart city. "For smart city residents to thrive, we must first put education in the spotlight," said Dr. I-Chang Tsai, vice president and CEO of digital education at the Taiwan Information Industry Institute. Smart cities recognize the need for "educational programs that provide graduates with up-to-date knowledge, practical skills and attitudes towards cooperation».[1].

Literature review. A.V.Zavrajin, V.V.Aleskovskiy, A.V.Nesterov, V.P.Tikhomirov,N.V.Komleva, G.A.Pollak, S.L.Eremina, P.N.Melnikov, S.V.Golovkova, A. M.Karmanov, NVTikhomirova, AVShiryay, Yu.F.Telnov, A.A.Aletdinova contributed to the introduction of SMART technologies in the educational process and the development of SMART education. N.V.Dneprovskaya, E.A.Yankovskaya, I.V.Shevtsova conducted research on such elements as smart-education, smart-school, smart-textbook, which are included in the concept of SMART education. Scientists such as Uskov, V.L., Bakken, J.P., Howlett, R.J., Jain, L.C., Vytautas Stuikys, Burlea, A.S, Burdescu, D.D, Gerval, J.P, Yann Le Ru developed the concept and technology of smart school.

Research Methodology. The methods of pedagogical observation, comparative analysis, study of documents, stratification were used in the preparation of the article.

Analysis and results. Smart education is a "learning model adapted to the new generations of digital natives". Compared to traditional classroom learning models, Intelligent Education is an interactive, collaborative and visual model designed to increase student engagement and allow teachers to adapt to learners' skills, interests and preferences.

In the past, "what students could see, hear and feel was confined to the classroom," says Professor Byung Guk Koo, a South Korean teacher and intellectual education pioneer who developed an interactive learning model with social media and the cloud. based on capabilities. Professor Ku believes 
that "one of the greatest opportunities offered by innovation in education is that students can communicate with the real world through new technologies."

Unfortunately, the adoption and effectiveness of educational technologies lagged behind other social trends, such as the rapid adoption by consumers of digital products and services. Now "increasingly digital and technologyoriented behavior of learners, teachers and parents expands learning opportunities" [1].

The influence of human capital is no longer sufficient for the development of modern education. It is necessary to change the educational environment itself, not just to increase the volume of education of labor resources, the content of education itself, its methods, tools and environments must change qualitatively, a universal transition to SMART education is necessary [2].

It is already becoming the norm to conduct training sessions with students using multimedia presentations made in software packages such as Microsoft Power Point or Macromedia Flash. However, along with the usual presentation technologies, new, so-called interactive technologies are penetrating into the field of education, which make it possible to get away from the presentation in the form of a slide show. A new form of presentation using interactive equipment (interactive whiteboards SMART Boards, interactive displays Sympodium) is a presentation created by the speaker during his speech - a presentation created here and now. On SMART Boards interactive whiteboards, you can write with a special marker, demonstrate educational material, and make written comments over the image on the screen. At the same time, everything written on the SMART Board interactive whiteboard is transferred to students, saved on magnetic media, printed, and sent by e-mail to students who are absent from class. Educational material created during a lecture on a SMART Board interactive whiteboard is recorded by a built-in video recorder and can be played back many times [2].

Existing classroom technologies in schools and other educational settings are often outdated and do not offer the functionality that modern digital and multimedia education should include to improve student engagement and learning outcomes. Smart cities need educational institutions and school systems that enable learners to acquire 21 st century skills, including "digital literacy, inventive thinking, effective communication, teamwork, and the ability to create high-quality projects. To achieve this noble goal, educators need to focus. technology on key building blocks of student achievement." A US Department of Education report states that "there is still a digital divide between students who use technology in active, creative ways to support their learning and those who predominantly use technology to support their learning. passive content consumption".

"Despite day-to-day use, there is room for growth in technology adoption 
in schools: $40 \%$ of teachers say their school is 'lagging behind' when it comes to technology adoption and adoption." The advantage of smart education is that it must enable teachers to meet the needs of learners with specific types of learning, such as those who are mostly visual learners. "Research shows that visual learners make up about $65 \%$ of the population, and $90 \%$ of information is conveyed visually. It is important to teach students strengths, especially when the content may not be memorable or exciting" [1]. Smart classroom technology supports the professionalization of the teaching process, helping teachers better prepare and enrich their lectures and respond flexibly to student needs and classroom conditions, resulting in more effective and efficient teaching. "In this student-centered context, "the teacher is no longer an authoritarian figure, but a guide, a teaching assistant in what is essentially a bi-directional process.

There are several technologies available to make your whiteboard interactive. One technology is resistive sensor technology, the other is DViT technology from SMART Technologies. It uses special digital video cameras located at the corners of the screen. In addition, with the help of a special attachment, you can turn any plasma panel into an interactive whiteboard. Of course, special software (SMART Notebook, Bridgit, SynhronEyes) has been created to maximize all the properties of SMART Boards. Each of these programs has its own characteristics. SMART Notebook lets you work with text and objects, save information, and turn written text into typed text. The Bridgit program makes it easy and quick to give presentations to partners around the world, get feedback on your document. As soon as you highlight the key positions of your speech on the common desktop, the program immediately displays all your notes in real time on the screens of the rest of the conference participants. With the help of the SynhronEyes software package, the teacher can keep track of what the students are doing, display all their working monitors on the blackboard, block their monitors, send educational material from the interactive whiteboard, for example, a test, to all computers $[2,3]$.

While working on interactive whiteboards, students improve their concentration, learn the learning material faster, and, as a result, improve the performance of each student. The introduction of new technologies in the field of education leads to a transition from the old scheme of the reproductive transfer of knowledge to a new, creative form of education. One of the main tasks of modern education is to create a stable motivation for students to acquire knowledge, the other is to search for new forms and tools for mastering this knowledge with the help of creative solutions.

The SMART society sets a new global task for schools: training personnel with creative potential, able to think and work in a new world. To do this, 


\section{EIP}

they need to be taught new practical skills: communicate in social networks, select useful information, work with electronic sources, compile personal knowledge bases, which requires a change in the nature of the educational process [4]. The content of the concept of smart schools in each country is interpreted differently, but in all cases, it boils down to a number of new effects that meet the needs of stakeholders in a new type of society.

SMART school assumes:

- flexibility of learning in an interactive educational environment;

- personalization and adaptation of training;

- free access to content around the world.

SMART training is implemented using technological innovations and the Internet, which provides students with the opportunity to acquire professional competencies based on a systemic multidimensional vision and study of disciplines, considering their multidimensionality and continuous updating of the content. Education in a SMART school should be as much as possible included in the life of the student, be informal, and also be based on technologies that are familiar to everyone today. To keep pace with the ongoing changes and the growing demands of SMART students, schools need to meet the following requirements: flexibility, adaptability, quality indicators, innovation [4].

Smart technologies are gaining great importance in education, on the one hand, they allow the school to optimize the costs of material and technical support, on the other hand, to bring the quality of educational services and products to a new level.

Smart Campus - a project supported by the European Commission, aimed at improving the efficiency of the equipment and energy resources used by the school through interaction with the main users (students, teachers, researchers).

Smart technologies are used in the implementation of educational programs, which consist not only in instrumental technologies for conducting the educational process (smart board, etc.), but in innovative curricula and disciplines. It is Smart technologies that make it possible to develop revolutionary educational and methodological materials, as well as to form individual learning paths for students.

The concept of SMART education includes:

1. Creation of an intellectual environment for the continuous development of the competencies of participants in the educational process, including activities of the formal and informal learning process, the result of which is changes in demonstrated behavior through the use of acquired new competencies.

The technical basis for the implementation of such education is the 
entire available park of devices both belonging to students and educational institutions: ordinary stationary computers, laptops, tablets, smartphones, etc.

2. The goal is to provide the skills necessary for successful activities in a digital society and smart economy [6].

Conclusion/Recommendations. I.V.Shubina defines the main characteristics of SMART education as:

- Seamlessness - ensuring compatibility between software developed for different operating systems. Seamlessness allows you to provide equal opportunities for learning, regardless of the devices used, ensuring the possibility of realizing the continuity of the educational process and the integrity of educational information.

- Independence from time and place, mobility, ubiquity, continuity and ease of access to educational information.

- Autonomy of the teacher and the student through the use of mobile devices to access educational information.

- Identification of various motivational models.

- The relationship between the individual and organizational goals of employers and the institution.

- Evaluation of the demonstrated changes in competencies - the effectiveness of the educational process is measured not so much by the knowledge gained as by the ability to apply it in practice.

- Flexible teaching in terms of the preferences and individual capabilities of the student (the ability to customize training for the individual student's parameters, including such as: initial knowledge, experience and skills; learning style; up to the physiological and psychological state at each specific moment of learning) [2 ].

References:

- Jon Glasco. SMART EDUCATION FOR SMART CITIES: VISUAL, COLLABORATIVE \& INTERACTIVE. 2019, https://hub.beesmart.city/ en/solutions/smart-people/smart-education/viewsonic-smart-education-forsmart-cities

- Shubina Irina Vladimirovna Smart and the development of modern education// Statistics and Economics. 2015. No. 3. URL: https://cyberleninka. $\mathrm{ru} /$ article/n/smart-i-razvitie-sovremennogo-obrazovaniya.

- Tikhomirov V.P. The world is on the way to Smart education. New opportunities for development // Open education. Scientific and practical journal. Special issue - "Smart Technologies in Education". - 2011.

- Humanitarian aspects of education, creativity and personal freedom: Collection of articles / M.E. Kudryavtseva. - M .: Direct-Media, 2014.

- Bekturova Zlikha Kaparovna. INTERACTIVE SMART TECHNOLOGIES IN LEARNING. Republican scientific and practical 
conference "Smart technologies in the system of advanced training: international experience and domestic practice" in the framework of the celebration of the 25th anniversary of the Independence of the Republic of Kazakhstan. 2016, https://zkoipk.kz/ru/2016smart3/2224-conf.html

- About tendencies in the field of education. Electronic resource: http:// ntihomirova.livejournal.com/44526.html 